\title{
Pengaruh Instagram @Feminist Terhadap Perubahan Pandangan Standar Kecantikan Wanita Indonesia
}

\author{
Andrea Yovanny Montana', Ahmad Junaidi \\ ${ }^{1}$ Fakultas Ilmu Komunikasi, Universitas Tarumanagara, Jakarta \\ Email: andrea.yovanny@gmail.com \\ ${ }^{2}$ Fakultas Ilmu Komunikasi, Universitas Tarumanagara, Jakarta* \\ Email:ahmadd@fikom.untar.ac.id
}

Masuk tanggal : 15-12-2021, revisi tanggal : 06-01-2022, diterima untuk diterbitkan tanggal : 16-01-2022

\begin{abstract}
The daily life of Indonesian people have been affected a lot by social media. Communication is more often done through social media than in person, especially during the pandemic. This makes social media have a big influence on people's perceptions. Social media that has a big influence on Indonesian society because of the large number of enthusiasts is Instagram.Instagram @ FEMINIST is an account that discusses feminism issues. One of the worrying issues of feminism is about women's beauty standards. The purpose of this study is to determine the effect of Instagram @ FEMINIST on changes in the views of Indonesian women's beauty standards. Quantitative methods is the method this study uses. The population in this study are followers of the @FEMINIST Instagram account. The sample taken is 100 respondents. Data was obtained by distributing questionnaires using a Likert scale with the indicators of Media Exposure and Body Image theory. The results of the Hypothesis Testing obtained using IBM SPSS version 22.0 For Windows obtained a significance value of $0.000<0.05$ with a $t$-count of $6.461>1.984$ so it can be concluded that the hypothesis test or t-test is acceptable. So HO is rejected and H1 is accepted, which shows that Instagram@FEMINIST exposure has a positive effect on the view of Indonesian women's beauty standards.
\end{abstract}

Keywords: Beauty Standards, Feminist, Instagram, Media Exposure.

\begin{abstract}
Abstrak
Kehidupan sehari-hari masyarakat Indonesia telah banyak dipengaruhi media sosial. Komunikasi lebih sering dilakukan melalui media sosial dibandingkan secara langsung, terutama saat masa pandemi. Hal ini membuat media sosial memiliki pengaruh besar terhadap persepsi masyarakat. Media sosial yang berpengaruh besar pada masyarakat Indonesia karena banyaknya peminat adalah Instagram. Instagram @FEMINIST merupakan akun yang membahas mengenai isu-isu feminisme. Salah satu isu feminisme yang mengkhawatirkan adalah tentang standar kecantikan wanita. Tujuan penelitian adalah untuk mengetahui pengaruh instagram @FEMINIST terhadap perubahan pandangan standar kecantikan wanita indonesia. Penelitian ini menggunakan metode kuantitatif. Populasi dalam penelitian ini adalah followers dari akun instagram @FEMINIST. Sampel yang diambil berjumlah 100 responden. Data diperoleh dengan menyebarkan kuesioner yang menggunakan skala likert dengan indikator teori Terpaan Media dan Body Image. Hasil Uji Hipotesis yang didapat menggunakan IBM SPSS versi 22.0 For Windows diperoleh nilai signifikansi sebesar $0,000<0,05$ dengan t hitung 6,461 >1,984 kesimpulannya adalah uji $\mathrm{t}$ uji hipotesis atau uji hipotesis dapat diterima. Hasilnya H0 ditolak dan H1 diterima, yang bermaksud Terpaan Instagram @FEMINIST berpengaruh positif terhadap pandangan standar kecantikan wanita Indonesia.
\end{abstract}

Kata Kunci: Feminis, Instagram, Standar Kecantikan, Terpaan Media. 


\section{Pendahuluan}

Media sosial merupakan suatu media online, yang membuat penggunanya dapat berbagi dan berpartisipasi menciptakan dan terhubung dengan orang lain yang juga menjadi pengguna(Ferlitasari et al., 2020) munculnya media baru di masyarakat disebabkan oleh perkembangan dunia modern yang semakin pesat, mengubah ruang lingkup kemungkinan sosio-teknis yang mempengaruhi komunikasi publik (Rusdi \& Sukendro, 2018). Salah satu media sosial yang berpengaruh sangat besar dalam membentuk pendapat masyarakat adalah Instagram. Menurut QNBC.com dalam(Anjani \& Irwansyah, 2020) menurut data terbaru Facebook Indonesia adalah negara di Asia Pasifik dengan pengguna Instagram terbesar di tahun 2019. Kehadiran berbagai media sosial terutama media Instagram mengakibatkan presentasi diri berkembang dengan pesat. Dalam menunjukkan diri dihadapan khalayak luas, Instagram sebagai salah satu media sosial memberikan sarana, maka dapat mempengaruhi perilaku presentasi diri (damayanti \& Purworini, 2018). Instagram telah membuat masyarakat berkompetisi untuk menunjukan hidup yang lebih baik, pekerjaan yang bergengsi, barang-barang mahal, mobil mewah. Selain hal- hal material, penampilan adalah highlight dari unggahan di Instagram dan hal itu menyebabkan standar kecantikan bagi wanita semakin penting.

Tekanan sosial yang membuat para wanita merasa harus mencapai standar kecantikan agar tidak menerima judgement dari masyarakat. Masyarakat Indonesia sangat beragam dan penampilan individu sangat berbeda dari 1 daerah ke daerah lainnya, maka mustahil untuk mengikuti standar kecantikan karena setiap orang dilahirkan dengan bentuk fisik yang berbeda-beda. Istilah insecure jadi lebih sering terdengar dan kaum wanita menjadi lebih mudah merasa kurang atau tidak percaya diri, karena adanya standar yang diterapkan oleh masyarakat Indonesia khususnya dalam media sosial Instagram. Terjadi diskriminasi berdasarkan penampilan dan hal itu merupakan bentuk ketidakadilan. Gerakan feminis muncul karena adanya banyak ketidakadilan yang diterima kaum perempuan. Dengan adanya media sosial, gerakan feminis semakin terbuka lebar dan para pendukungnya semakin banyak. Instagram @FEMINIST adalah akun yang menyuarakan mengenai hak- hak perempuan. Akun ini sering membagikan gambar-gambar perempuan yang berbeda-beda warna kulit dan bentuk tubuh untuk mendobrak stigma masyarakat yang menilai bahwa cantik adalah berkulit putih dan bertubuh ramping.Bagaimana konten media menerpa pemirsa atau kondisi dimana pemirsa diterpa oleh konten media dan perilaku pemirsa dalam menggunakan media massa adalah pengertian terpaan media(Marta \& William, 2017). Terpaan media merupakan bagaimana faktor- faktor audiens dalam menggunakan media mempengaruhi terpaan media pada audiens.

Berdasarkan paparan latar belakang, maka fokus permasalahan di penelitian ini adalah bagaimana pengaruh Instagram @FEMINIST terhadap perubahan pandangan standar kecantikan wanita Indonesia? Berdasarkan tuturan rumusan masalah, maka penelitian ini bertujuan untuk mengetahui pengaruh Instagram @ FEMINIST terhadap perubahan pandangan standar kecantikan wanita Indonesia.

\section{Hipotesis}

H0 : Variabel bebas (pengaruh Instagram @FEMINIST) tidak berpengaruh secara signifikan terhadap variabel terikat (pandangan standar kecantikan wanita Indonesia). H1 : Variabel bebas (pengaruh Instagram @FEMINIST) berpengaruh secara signifikan terhadap variabel terikat (pandangan standar kecantikan wanita Indonesia). 
Andrea Yovanny Montana, Ahmad Junaidi: Pengaruh Instagram @Feminist Terhadap Perubahan Pandangan Standar Kecantikan Wanita Indonesia

\section{Metode Penelitian}

Kuantitatif merupakan pendekatan penelitian ini. Penelitian kuantitatif dilakukan dengan menyelesaikan masalah atas dasar deduksi teori atau menguji hipotesis, dengan menggunakan data statistik sebagai pengukuran.

Populasi penelitian ini merupakan followers dari Instagram @FEMINIST. Jumlah total followers Instagram @ FEMINIST adalah 6.400.000 orang dari seluruh dunia. Sampel dari penelitian ini adalah followers dari Instagram @FEMINIST. Sampel sejumlah 100 orang setelah dihitung menggunakan rumus Slovin. Peneliti menggunakan metode probability sampling dalam penelitian ini yaitu memilih sampel dari populasi secara acak.

Menurut Sugiyono dalam (Sulistiyo et al., 2020) untuk mengetahui nilai dari sebuah variabel independent tanpa menghubungkannya dengan variabel lain, kemudian mengintepretasikan nilai tadi dalam tulisan sistematis penelitian yang menggunakan metode kuantitatif. Metode survey adalah metode pengumpulan data penelitian ini dengan instrumen kuesioner. Mengumpulkan data dilakukan melalui pemberian pertanyaan atau pernyataan yang telah disiapkan untuk dijawab oleh responden adalah pengertian kuesioner. Instrumen kuesioner efisien bila variabel yang diukur sudah diketahui pasti.

Teknik analisis data penelitian ini dengan metode kuantitatif. Dengan metode ini, pengolahan data dilakukan dengan menghitung skor berdasarkan skala Likert. Skala Likert yang dipakai penelitian ini merupakan modifikasi skala Likert. Dengan mendiadakan jawaban tengah yang berarti netral, peneliti dapat melihat lebih jelas jawaban tidak setuju atau setuju.

Uji yang dilakukan pada penelitian ini, Uji koefisien korelasi berguna untuk mengetahui besaran hubungan variabel bebas dan terikat yaitu Variabel (X) pengaruh Instagram @FEMINIST, dan variabel (Y) pandangan standar kecantikan wanita Indonesia. Uji korelasi penelitian ini menggunakan uji korelasi Pearson, Uji T merupakan uji yang berguna untuk menguji kepalsuan atau kebenaran dari hipotesis nol Sudjiono dalam (Zein et al., 2019) Hipotesis penelitian sebagai berikut:

H0 : Variabel bebas (pengaruh Instagram @FEMINIST) tidak mempunyai pengaruh yang signifikan terhadap variabel terikat (pandangan standar kecantikan wanita Indonesia).

H1 : Variabel bebas (pengaruh Instagram @FEMINIST) mempunyai pengaruh yang signifikan terhadap variabel terikat (pandangan standar kecantikan wanita Indonesia).

Uji Persamaan regresi linier sederhana adalah model persamaan yang menggambarkan hubungan antara variabel bebas/variabel prediktor $(\mathrm{X})$ dan variabel terikat/respon (Y) (Fisika et al., 2016). Persamaan regresi linier sederhana secara matematik dirumuskan dengan :

$$
\begin{aligned}
& \mathrm{Y}=\mathrm{a}+\mathrm{bX} \\
& \text { penjelasan : } \\
& \mathrm{Y}^{\wedge}=\text { variable response /garis regresi } \\
& \mathrm{a}=\text { perpotongan dengan sumbu vertikal, konstanta (intersep } \\
& \mathrm{b}=\text { konstanta regresi (slope) } \\
& \mathrm{X}=\text { predictor /variabel bebas }
\end{aligned}
$$




\section{Hasil Temuan dan Diskusi}

Populasi penelitian ini adalah followers Instagram @FEMINIST, sejumlah 100 orang sampel yang diambil setelah dihitung menggunakan rumus Slovin. Pengambilan sampel menggunakan simple random sampling. Responden dapat dikategorikan berdasarkan data pribadi yang telah diisi. Tabel di bawah ini menjelaskan karakteristik identitas responden:

Tabel 1. Karakteristik Responden

\begin{tabular}{|c|c|c|c|c|}
\hline Kategori & Sub Kategori & Frekuensi & Presentase & Total \\
\hline Jenis Kelamin & $\begin{array}{c}\text { Wanita } \\
\text { Pria }\end{array}$ & $\begin{array}{l}73 \\
27\end{array}$ & $\begin{array}{l}73 \% \\
27 \%\end{array}$ & $100 \%$ \\
\hline Usia & $\begin{array}{c}<15 \text { Tahun } \\
15-26 \text { Tahun } \\
>26 \text { Tahun }\end{array}$ & $\begin{array}{c}0 \\
98 \\
2\end{array}$ & $\begin{array}{c}0 \% \\
98 \% \\
2 \%\end{array}$ & $100 \%$ \\
\hline $\begin{array}{c}\text { Pendidikan } \\
\text { Terakhir }\end{array}$ & $\begin{array}{c}\text { SD } \\
\text { SMP } \\
\text { SMA } \\
\text { Diploma } \\
\text { S1 } \\
\text { S2 } \\
\text { S3 } \\
\end{array}$ & $\begin{array}{c}0 \\
0 \\
76 \\
1 \\
22 \\
0 \\
1 \\
\end{array}$ & $\begin{array}{c}0 \% \\
0 \% \\
76 \% \\
1 \% \\
22 \% \\
0 \% \\
1 \% \\
\end{array}$ & $100 \%$ \\
\hline Pekerjaan & $\begin{array}{c}\text { Pelajar } \\
\text { Mahasiswa } \\
\text { Karyawan Swasta } \\
\text { PNS } \\
\text { Wirausaha } \\
\end{array}$ & $\begin{array}{c}2 \\
90 \\
4 \\
0 \\
4 \\
\end{array}$ & $\begin{array}{c}2 \% \\
90 \% \\
4 \% \\
0 \% \\
4 \% \\
\end{array}$ & $100 \%$ \\
\hline
\end{tabular}

Sumber: Hasil Data Penelitian 2021

Profil responden berdasarkan Jenis Kelamin di penelitian ini menjelaskan bahwa terdapat 73 responden dengan jenis kelamin Wanita dan 27 responden dengan jenis kelamin Pria. Kebanyakan responden dalam penelitian ini merupakan Wanita, Hal ini dikarenakan followers Instagram @FEMINIST didominasi oleh wanita. Karena konten Instagramnya yang membahas mengenai feminis yaitu gerakan kesetaraan terutama bagi kaum perempuan, maka tidak mengherankan bahwa followersnya kebanyakan wanita.

Profil responden berdasarkan usia yang memperlihatkan bahwa usia responden dalam penelitian ini, berusia antara 15-26 tahun yakni 98\% atau sejumlah 98 orang. Kemudian responden yang berusia $>26$ tahun $2 \%$ atau sejumlah 2 orang. Responden penelitian ini di dominasi oleh pengunjung yang berusia 15-26 tahun, ini disebabkan karena sebagian besar pengguna Instagram merupakan Generasi Z. Profil responden berdasarkan pendidikan terakhir responden menunjukan responden dalam penilitian ini di dominasi oleh SMA sebanyak 76 orang atau $76 \%$, kemudian diikuti oleh Sarjana S1 sebanyak 22 orang atau 22\%, Diploma 1\% atau sejumlah 1 orang, Doktor S3 $1 \%$ atau sebanyak 1 orang dan responden yang pendidikan terakhirnya SD, SMP, dan S2 adalah 0. Profil responden kategori pekerjaan, maka diketahui bahwa pekerjaan responden didominasi oleh Mahasiswa yakni sebanyak 90 orang 
atau 90\%, kemudian 4 orang atau $4 \%$ untuk Karyawan Swasta dan Wirausaha, sejumlah 2 orang atau $2 \%$ pelajar, dan yang bekerja sebagai PNS sebanyak 0 .

Model persamaan regresi dari penelitian ini menggunakan rumus persamaan regresi linear sederhana yaitu $Y=\mathbf{3 4 . 1 6 1}+\mathbf{0 , 3 2 0 X}$. dengan Output SPSS sebagai berikut:

Tabel 2. Hasil Regresi Sederhana Coefficients $^{\mathbf{a}}$

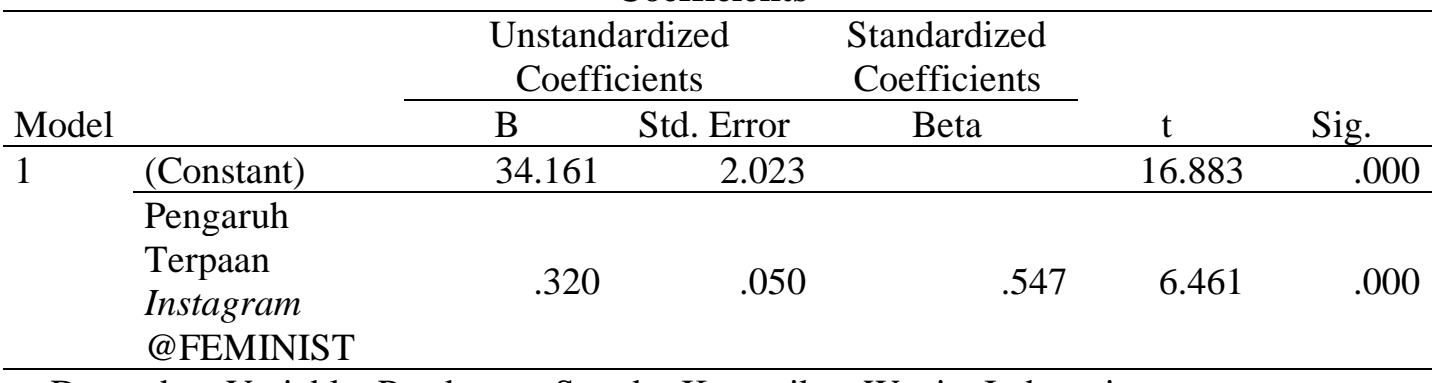

a. Dependent Variable: Pandangan Standar Kecantikan Wanita Indonesia

Sumber: Hasil SPSS 22.0 For Windows

Hasil uji signifikan menemukan $p$ value $0.000<0,05$. Pada tabel diatas, kolom B nilai consant (a) sebesar 34.161 dan sedangkan nilai dari variable Pengaruh Terpaan Instagram @FEMINIST yaitu sebesar 0,320. Persamaan tersebut dapat diterjemahkan bahwa konstanta a dengan nilai 34.161 berarti bahwa nilai konsisten variabel Pandangan Standar Kecantikan Wanita Indonesia sebesar 34.161. Koefisien regresi tersebut bernilai positif, karena nilai $\mathrm{b}$ tidak tidak mengandung nilai minus yang dapat diketahui bahwa arah pengaruh variabel $\mathrm{X}$ terhadap $\mathrm{Y}$ adalah positif.

Tabel 3. Hasil R Square

\begin{tabular}{lccccc}
\hline \multicolumn{6}{c}{ Model Summary } \\
\hline Model & $\mathrm{R}$ & R Square & Adjusted R Square & $\begin{array}{c}\text { Std. Error of the } \\
\text { Estimate }\end{array}$ \\
\hline 1 & $.547^{\text {a }}$ & .299 & & .292 & 4.616 \\
\hline a. Predictors: (Constant), Total_X & & & \\
\hline
\end{tabular}

Sumber: Hasil SPSS 22.0 For Windows

R Square senilai 0,299. Nilai ini berarti bahwa Pengaruh Terpaan Instagram @FEMINIST atau variabel $\mathrm{X}$ terhadap Pandangan Standar Kecantikan Wanita Indonesia atau variabel $\mathrm{Y}$ adalah sebesar $29,9 \%$ sedangkan $70,1 \%$ lainnya dipengaruhi oleh variabel lain yang tidak diteliti. 
Tabel 4. Hasil Uji Koefisien Korelasi

\begin{tabular}{|c|c|c|c|}
\hline \multicolumn{4}{|c|}{ Correlations } \\
\hline & & $\begin{array}{c}\text { Terpaan Instagram } \\
@ \text { FEMINIST }\end{array}$ & $\begin{array}{l}\text { Pandangan Standar } \\
\text { Kecantikan Wanita } \\
\text { Indonesia }\end{array}$ \\
\hline \multirow{3}{*}{$\begin{array}{l}\text { Terpaan } \\
\text { Instagram } \\
\text { @FEMINIST } \\
\end{array}$} & Pearson Correlation & 1 & $.547^{* *}$ \\
\hline & Sig. (2-tailed) & & .000 \\
\hline & $\mathrm{N}$ & 100 & 100 \\
\hline Pandangan & Pearson Correlation & $.547^{* *}$ & 1 \\
\hline Standar & Sig. (2-tailed) & .000 & \\
\hline $\begin{array}{l}\text { Kecantikan } \\
\text { Wanita } \\
\text { Indonesia }\end{array}$ & $\mathrm{N}$ & 100 & 100 \\
\hline **. Correlatic & gnificant at the 0. & (2-tailed). & \\
\hline
\end{tabular}

Sumber: Hasil SPSS 22.0 For Windows

Diketahui hasil nilai Sig. (2- tailed) koefisien korelasi sebesar 0.000 yang lebih kecil dari taraf signifikansi $(\alpha=0.05)$ dan nilai Pearson dari tabel sebesar 0,547 maka dapat dikatakan ada korelasi positif diantara dua variabel Terpaan Instagram @FEMINIST atau variabel X terhadap Pandangan Standar Kecantikan Wanita Indonesia atau variabel Y sebesar 0,547 dan memiliki signifikansi sedang.

Tujuan dari Uji hipotesis yaitu untuk menemukan apakah ada pengaruh antara variable Terpaan Instagram @FEMINIST atau variabel X terhadap Pandangan Standar Kecantikan Wanita Indonesia atau variabel Y. Penelitian ini dilakukan uji hipotesis dengan menggunakan Uji T. Hipotesis pada penelitian ini :

H0 : Variabel bebas (pengaruh Instagram @FEMINIST) tidak berpengaruh secara signifikan terhadap variabel terikat (pandangan standar kecantikan wanita Indonesia).

H1 : Variabel bebas (pengaruh Instagram @FEMINIST) berpengaruh secara signifikan terhadap variabel terikat (pandangan standar kecantikan wanita Indonesia).

Tabel 5. Hasil Uji T

\begin{tabular}{|c|c|c|c|c|c|c|}
\hline \multicolumn{7}{|c|}{ Coefficients $^{\mathrm{a}}$} \\
\hline \multirow[b]{3}{*}{ Model } & & \multirow{2}{*}{\multicolumn{2}{|c|}{ Unstandardized Coefficients }} & Standardized & \multirow[b]{3}{*}{$\mathrm{t}$} & \multirow[b]{3}{*}{ Sig. } \\
\hline & & & & Coefficients & & \\
\hline & & $\mathrm{B}$ & Std. Error & Beta & & \\
\hline \multirow[t]{2}{*}{1} & (Constant) & 34.161 & 2.023 & & 16.883 & .000 \\
\hline & Total_X & .320 & .050 & .547 & 6.461 & .000 \\
\hline
\end{tabular}

a. Dependent Variable: Total_Y

Sumber: Hasil SPSS 22.0 For Windows

Variabel Terpaan Instagram @FEMINIST sejumlah 6,461 t hitung dan sejumlah 0,000 nilai signifikan. Jikalau $\mathrm{t}$ tabel lebih kecil dari $\mathrm{t}$ hitung dan signifikansi lebih kecil dari $0,05(<0,05)$ maka dapat diterima hipotesis. Hasil penelitian ini dilihat bahwa nilai signifikansi sebesar $0,000<0,05$ dengan thitung 6,461 > 1,984 hasilnya disimpulkan bahwa uji $\mathrm{t}$ atau uji hipotesis diterima. H1 diterima dan H0 ditolak, kemudian memperlihatkan pengaruh positif Terpaan Instagram@FEMINIST terhadap pandangan standar kecantikan wanita Indonesia. 
Andrea Yovanny Montana, Ahmad Junaidi: Pengaruh Instagram @Feminist Terhadap Perubahan

\section{Simpulan}

Hasil uji signifikan menemukan $p$ value $0.000<0,05$. Kolom B nilai consant (a) sebesar 34.161 dan sedangkan nilai dari variable Pengaruh Terpaan Instagram @FEMINIST yaitu sebesar 0,320. Persamaan tersebut dapat diterjemahkan bahwa konstanta a dengan nilai 34.161 yang memiliki arti nilai konsisten variabel Pandangan Standar Kecantikan Wanita Indonesia sebesar 34.161. Koefisien regresi tersebut bernilai positif, karena nilai $\mathrm{b}$ tidak tidak mengandung nilai minus kemudian dapat diketahui bahwa arah pengaruh variabel $\mathrm{X}$ terhadap $\mathrm{Y}$ adalah positif.

Hasil Uji Hipotesis diperoleh nilai signifikansi sejumlah $0,000<0,05$ dengan t hitung 6,461 > 1,984 kemudian kesimpulannya adalah uji t atau uji hipotesis diterima. Hasilnya $\mathrm{H} 1$ diterima dan $\mathrm{H} 0$ ditolak, yang memperlihatkan Terpaan Instagram @FEMINIST memiliki pengaruh yang positif terhadap pandangan standar kecantikan wanita Indonesia.

Diketahui hasil nilai Sig. (2- tailed) koefisien korelasi sejumlah 0.000 yang dapat dinyatakan lebih kecil dari taraf signifikansi $(\alpha=0.05)$ dan nilai Pearson dari tabel sejumlah 0,547 maka dapat dikatakan ada korelasi positif diantara dua variabel dan memiliki signifikansi sedang.

Hasil perhitungan R Square sejumlah 0,299. Nilai artinya adalah Pengaruh Terpaan Instagram @FEMINIST atau variabel X terhadap Pandangan Standar Kecantikan Wanita Indonesia atau variabel Y adalah sebesar 29,9\% dan 70,1\% lainnya dipengaruhi oleh variabel lain yang tidak diteliti.

\section{Ucapan Terima Kasih}

Pertama penulis terima kasih kepada Tuhan Yang Maha Esa, dan mengucapkan terima kasih kepada orang tua dan teman- teman yang selalu memberikan dukungan, juga kepada dosen pembimbing, Universitas Tarumanagara, dan seluruh pihak yang membantu, mendukung dan mendoakan.

\section{Daftar Pustaka}

Anjani, S., \& Irwansyah, I. (2020). PERANAN INFLUENCER DALAM MENGKOMUNIKASIKAN PESAN DI MEDIA SOSIAL INSTAGRAM [THE ROLE OF SOCIAL MEDIA INFLUENCERS IN COMMUNICATING MESSAGES USING INSTAGRAM]. Polyglot: Jurnal Ilmiah, 16(2), 203-229. https://ojs.uph.edu/index.php/PJI/article/view/1929

damayanti, alfi, \& Purworini, D. (2018). Pembentukan Harga Diri: Analisis Presentasi Diri Pelajar SMA di Media Sosial. Jurnal Komunikasi, 10(1), 3347. https://doi.org/10.24912/JK.V10I1.1282

Ferlitasari, R., . S., \& Rosana, E. (2020). PENGARUH MEDIA SOSIAL INSTAGRAM TERHADAP PERILAKU KEAGAMAAN REMAJA. Sosio Religia, 1(2). http://ejournal.radenintan.ac.id/index.php/sr/article/view/8435

Fisika, J., Matematika, F., Ilmu, D., \& Alam, P. (2016). REGRESI LINIER SEDERHANA Disusun oleh : I MADE YULIARA.

Marta, R. F., \& William, D. M. W. M. (2017). STUDI TERPAAN MEDIA PEMASARAN MELALUI POSTING INSTAGRAM TERHADAP EKUITAS MEREK PELANGGAN SUMOBOO! Jurnal Komunikasi, 8(1), 68-82. https://journal.untar.ac.id/index.php/komunikasi/article/view/50 
Rusdi, F., \& Sukendro, G. G. (2018). Analisis Industri Kreatif Dalam Memanfaatkan Identitas Kota Melalui Media Baru. Jurnal Komunikasi, 10(1), 95-102. https://journal.untar.ac.id/index.php/komunikasi/article/view/1221

Sulistiyo, T., Sulistiyo, T. D., \& Fitriana, R. (2020). Pengaruh Marketing Media Sosial Instagram Terhadap Brand Image The Bunker Café, Tangerang. JURNAL EKBIS, 21(2), 189-203. https://doi.org/10.30736/je.v21i2.512

Zein, S., Yasyifa, L., Ghozi, R., Harahap, E., Badruzzaman, F., \& Darmawan, D. (2019). Pengolahan dan Analisis Data Kuantitatif Menggunakan Aplikasi SPSS. Jurnal Teknologi Pendidikan Dan Pembelajaran, 4(1), 1-7. 